ROCZNIKI PEDAGOGICZNE

Tom 13(49), numer $2-2021$

DOI: https://doi.org/10.18290/rped21132.10

ARLETA SUWALSKA

\title{
VALUES AND THEIR INFLUENCE ON LEARNING \\ IN BASIC EDUCATION IN FINLAND \\ - SELECTED ASPECTS
}

\begin{abstract}
There will be almost a revolution in school education when study and learning are treated not as acquisition of what others know but as development of capital to be invested in eager alertness in observing and judging the conditions under which one lives. Yet until this happens, we shall be ill-prepared to deal with a world whose outstanding trait is change.
\end{abstract}

Dewey $(1944 / 1991, p .463)$

Berkowitz (1995, 1996) and Oser (1994), who conducted research of values in terms of subjective judgments and behaviour, postulate that people do not need many values to improve their moral attitude towards judgments and actions. According to Chałas "value is everything that is valuable, important and worthy of man, groups and human communities, which lead to their integral development, to full humanity, to the development of social integration which is immersed in the construction of the common good" (2011, p. 19). Mariański (2000, p. 225) claims that values contribute to "more general and permanent orientations which define life prospects of everyday life." In this scientific perspective I would like to pay attention to values, which could be perceived as pillars of learning in basic education in Finland. In addition, I concentrate on the phenomena of equality and trust, conception of learning and collaboration among teachers in Finnish basic education.

Dr. ARLeTA SuWALSKA - Faculty of Educational Sciences, University of Łódź; address for correspondence: ul. Pomorska 46/48, 91-408 Łódź; e-mail: arleta.suwalska@uni.lodz.pl; ORCID: https://orcid.org/0000-0003-0713-8451. 


\section{VALUES IN CONTEMPORARY EDUCATION AND LEARNING IN THE 21 CENTURY}

According to Homplewicz, values are "everything that is valuable to people, everything that we want to engage our efforts and our will" (1996, p. 142). In this light, Łobocki claims that "value is an important basis for recognizing something is good or bad" $(2000$, p. 72$)$. Berkowitz $(1995,1996)$ and Oser (1994), who conducted research of values in terms of subjective judgments and behaviour, postulate that people do not need many values to improve their moral attitude towards judgments and actions. Berkowitz (1997) underlines regulative function of values and their characteristics or so-called 'meta-morals.'

In Nowak's opinion (2019, p. 18), "the teacher, apart from the pedagogical talent in showing specific values and causing the pupil's fascination with them, is also a significant support for the student and becomes his or her testimony of living with these values." Veugelers (2001) added that teachers are obliged to study their own values as well as to monitor their students' values and development them from the perspective of critical pedagogy. In this light, Paul (1992) and Enni (1994) confirm that students need to develop their own reflections based on values. The varied, also polictical implications and dimensions of values are omnipresent in the curriculum and contribute to students' successful learning.

In this perspective, Core Education (p. 1) reveals that the drivers of learning orientation are related to two significant factors: the learner's orientation towards learning and learners support by school and community. Students, as learners, are encouraged to study by outcomes, grades or certificates to obtain required skills to find out job. Pollio \& Beck (2000) claims that students who focus on gaining knowledge to study new information are learning oriented. Taking into account learning, values "are not personal preferences based on taste; they are judgements based on more or less explicit and systematic ideas about how a person relates to his/her environment" (Veugelers \& Vedder, 2003, p. 379). Teachers and students have their sets of values, which "collaborate" in education. The International Commission on Education for the Twenty-first Century, identified the Pillars of Learning in the 21 st Century "learning to know, learning to live together, learning to do, and learning to be" (Learning to live together, p. 94). Teachers have the will to influence on the students' values and on moral functioning of school perceived as a learning organisation. As Chałas and Winiarczyk (2018, p. 144) 
added, "people learn specific moral norms and values which are significant drivers of their activities."

\section{RESEARCH QUESTIONS AND METHODOLOGY}

In order to present values in education from a Finnish perspective I formulated the following research questions: 1) What values are included in the curriculum? 2) What are the strengths of values in learning in Finnish education? The main part of our study was an analysis of values in the National Core Curriculum for Basic Education 2014 in Finland. Analysis of the curriculum began with a review of the literature on values in education. The next step was to concentrate on the phenomenon of equality and trust, conception of learning and collaboration among teachers in Finnish basic education.

I employed the problem method including the study of documents (Wodak \& Krzyżanowski, 2008, p. 156). The problem method, originated from an educational phenomenon, is placed in time and related to particular society. From this perspective, it is necessary to contrast different views and principles, in this case in Finnish education. In this article, I intended to use primary rather than secondary sources. The most important step was the analysis of materials accessed at the library at the University of Helsinki. The next step was the choice of materials for final analysis.

\section{JOHN DEWEY AND HIS INFLUENCE ON FINNISH BASIC EDUCATION}

According to Sahlberg, the most influential person, whose works had a big influence on Finnish educational system, was an American philosopher John Dewey. He emphasized on the students' learning experiences which provides a bridge between "me and society, between self-realization and democratization" (Pinar, 2004, p. 13). The influence of Dewey's pedagogy on learning is significant. Dewey's views on democracy education, "making it easier for students to make decisions about their own life and learning at school" (Five U.S. innovations). According to Dewey, upbringing is like a laboratory in which philosophical formulations of issues are applied and tested. These formulations shape students' intellectual and moral behavior 
and enable them freely and actively participate in social life. For Dewey, upbringing is "the process of the individual's growing into the social consciousness of the species" (Chmaj, 1962, p. 252), the process which transfers the intellectual and moral resources acquired by humanity in the course of its development.

Dewey's views on education are based on the critique of traditional education described in his work Education and Experience (Dewey, 1958, p. 2). Burnett, analyzing Dewey's contribution to education, warns against identifying his experimentalism with pedagogical progressivism (Burnett, 1981, pp. 66-67). The foundations for future progressivism should be found in Rousseau's naturalism and his education to freedom, as well as in Pestalozzi's method of formulating concepts based on sensory experiences. Dewey also used the teaching method developed by Swiss educator Heinrich Pestalozzi to formulate precise concepts based on sensory perceptions. Pestalozzi based his subject lesson on teaching form, number and name. The students' task according to Dewey was to define the shape of objects, count and name them (Gutek, 1968, pp. 88-93). On the other hand, the religious upbringing of John Dewey in the Protestant Evangelical Church, which was influenced by the "social gospel" contribute to his moral duty of man to reform the rules of global order. Additionally, people should work to improve the welfare of society and to repair social relations (Gutek, 1968). The above-described scientific ideas laid the foundations for the equality and trust of the Finnish education system which shape underlying values of basic education, conception of learning and teachers' collaboration.

\section{EQUALITY AND LEARNING IN FINNISH EDUCATION}

The phenomenon of educational equality has became the basic pillar of learning in Finland since the end of the 1960s. Gmerek (2005, p. 226) claims that ,education is an integral part of complex social processes and phenomena" According to Sahlberg (2015, p. 149) because schooling "is strongly influenced by the family background of children and related factors, equality of results requires that schools are funded in line with real needs in order to deal with these inequalities."

It seems indispensable to mention that this educational and equity phenomenon is represented in Finnish society. To overcome inequality at schools there was introduced a Finnish system of public teacher education, teachers 
collaboration and teaching methods adapted to the needs and abilities of students (Suwalska, 2020). The people, who critisized the new system claimed that it was not easy to create the same educational expectations for children coming from very varied social and intellectual circumstances, but fortunately it works according the smallest variance within and between schools in students mathematics performance on the PISA 2012, PISA 2015 (OECD, 2013; OECD, 2018, p. 5). These factors confirm that Finland is a constant member of the countries that have above-average equity (Ustun \& Eryilmaz, 2018, p. 95), what is also seen in education in Singapore (Nowosad, 2018, pp. 105-126).

To introduce equality, Finnish basic schools employ special education teachers and classroom assistants who instantly react on school students' needs. Besides, "special education" is designed to help all students in basic education, taking into account the statement that at certain moments in our school lives each person needs help. In addition, the feature of Finnish "special education" is prevention, understood as a strategy of early intervetion to prevent future problems.

To enable Finnish schools work more efficiently, there was introduced Finnish peruskoulu (primary school) in 1970s (Kupiainen, Hautamäki, \& Karjalainen, 2009) which is based on the connection which involve existing grammars chools, civic schools, and primary schools into a 9-year comprehensive school. As a consequence, students in spite of varied living situations and socioeconomic status could participate in lessons in the same 9-year basic schools led by local education authorities.

\section{TRUST AND LEARNING IN FINNISH EDUCATION}

The second pillar of learning is trust, which is often named as a culture of trust or distrust. It is a general process in which "cultures, social structures, normative systems, institutions and organizations are formed and crystallized" (Sztompka, 2007, p. 272). Trust is perceived as a crucial element in the flourishing organizations. Trust is indispensable for efficient co-operation and communication which rely on productive relationships (Baier, 1985, pp. 95-96). If there is distrust "people are increasingly unwilling to take risks, demand greater protections against the possibility of betrayal, and increasingly insist on costly sanctioning mechanisms to defend their interests" (Tyler \& Kramer, 1996, pp. 3-4). As a result, trust has been named as the 
"foundation of school effectiveness" (Cunningham \& Gresso, 1993). Trust allows teachers focus on the school tasks and helps build effective schools, what we also observe in Singapore (Łukasik \& Nowosad, 2019, pp. 173-189).

In this perspective of social equality in schools, Finnish society "trust their teachers and heads of schools" (Suwalska, 2018, p. 275). Tirri claims that decentralization of Finnish system of education allowed teachers use "a great deal of professional freedom in curriculum design, teaching methods and learning materials" (2014, p. 603). Teachers have also been trusted to do their best as true professionals. As a result, Finnish teachers are perceived as independent and enjoy autonomy in organising their schoolwork which is based on the national core curriculum. Consequently, trust is seen everywhere in Finnish education and is closely linked to "culture of trust within the education system" (Sahlberg, 2015, p. 149). In this light, it seems necessary to mention that in Finnish culture, the teachers' profession is perceived as "one of the most important professions" (Kupari, Reinikainen, Linnakylä, Arffman, \& Välijärvi, 2002, p. 42). Consequently, Finns invested a lot of resources in teachers education.

Principals in Finnish schools are priceless due to the social trust related to their practical knowledge how to solve school problems. If school has problems, the head of local municipalities ask: "How we can help the school? What were the things that went wrong? The knowledge is in the school and we have capable principals. You have to trust. Trust is the first thing" (Sahlberg, 2015, p. 149).

\section{THE CONCEPTION OF LEARNING IN FINNISH BASIC SCHOOLS}

Finns introduced the new educational theoretical and methodological basics of education and the new rules in conception of learning and knowledge in basic education. I was done simultaneously with the introduction of equality and trust in educational system. Despite varied children's place of residence, their gender and family social status schools were obliged to enhance the equality of educational opportunities. Learning is perceived as "and inseparable part of an individual's growth as a human being and a building a decent life for humanity" (National Core Curriculum for Basic Education, 2014, p. 17) in Finland.

The acquisition of new knowledge, skills is based on students' learning, experiences and emotions. Affirmative emotional experiences contribute to 
students creative learning which full of joy and development. If students are involved in the learning process they improve their skills. Consequently, they are able to think critically, solve problems and are able to present varied viewpoints. It is done according to learning diversity and related to particular time and place. If teachers develop students' learning skills they contribute to their goal-oriented and lifelong learning. Students who "are aware of and responsible for their learning processes will increasingly learn self-regulation" (National Core Curriculum for Basic Education, 2014, p. 17).

In this light, it makes sense to mention that according to National Core Curriculum for Basic Education 2014 (p. 17) students interests, working approaches, experiences and emotions influence on the whole process of learning. The high-level of self-image, self-efficacy and self-esteem has a positive influence on students learning goals and their participation in them. In addition, the documents underlines the need of positive and constructive feedback in expanding and enhancing students attitude towards learning.

\section{VALUES IN BASIC EDUCATION IN FINLAND}

National Core Curriculum for Basic Education in Finland defines the main goals for school subjects. Basic education values had its roots in philosophy, humanities, and social sciences (2014, p. 15). It treats each child as unique, valuable and stresses his or her uniqueness and right to improve skills as a human being and as a part of democratic society. The document underlines the right of each child to a good education to work together 'to advance the functioning and welfare of the community' (p. 15), learning is perceived as a process which helps students to build their identity, worldviews and philosophy of life to help find own place in the world. National Core Curriculum for Basic Education 2014 put an emphasis on understanding other people, ,the society, the environment and different cultures' (p. 15). It is suggested that in Finnish lessons values enable students to build their own valuable life. Consequently, students acquire a set of values indispensable in their lives and to think critically about them. All in all, schools support students in building their systems of values. Students' holistic well-being in basic education is built through co-operation between the values promoted in schools and in their homes.

Apart from the right of each child to a good education, the document emphasises the support of children in their growth and stresses the need to as- 
pire to 'truth, goodness, beauty, justice and peace' (p. 16). In this perspective, each student is capable of making decisions which directly follow ethical reflections. The document puts into consideration the significance of the ethical and aesthetic perspective to teach students what is valuable in their lives. As a consequence, an educated person is prepared to perceive the surrounding reality in the perspective of his or her attitudes to his or her life and the environment, showing respect to other people.

National Core Curriculum for Basic Education 2014 in point 2.2 "Underlying values" underlines that 'respect for human life, human rights and human dignity' (p. 16) are the humanistic basis of this level of education in Finland. Education promotes well-being in a democratic society, and recommends 'economic, social, regional and gender equality' (p. 16). The document underlines 'cultural diversity as richness' and 'a diverse Finnish cultural heritage' (p. 16). Taking all this into consideration, students obtain help indispensable help to improve their own 'personal cultural identities' and their school development as valuable factors of their culture participation. Basic education influence on students' creativity and promotes interactions between cultures in the light of sustainable development. As a result, students from different cultures and linguistic backgrounds perceive different customs and beliefs as understandable for them. Students acquire skills which enable them recognise the circumstances and life situations of other people as a result of their study 'across the boundaries of languages, cultures, religions and beliefs' (p. 16).

The national core curriculum took into account 'humanity, general knowledge and ability, equality and democracy' (p. 16). The document supports each child's growth and to the child's 'truth, goodness, beauty, justice and peace' (p. 16). It underlines the need to teach students how solve these conflicts ethically and what are good parts of their general knowledge and abilities. The document underlines that 'general knowledge and ability manifest themselves in our attitudes to ourselves, other people, the environment and information, in the ways we act and in our willingness to take action' (p. 16). In this educational perspective, it is emphasised that basic education is based on respect for human life and rights in order to promote well-being, democracy which are involved in basic education curriculum to promote economic, social, regional, and gender equality.

Viewed from the perspective of the basic curriculum in Finland, especially underlying values education in Finland declares sustainable development and eco-social knowledge to rely on the vitality of ecosystems and confirm the 
'necessity of a sustainable way of living.' Eco-social knowledge creates understanding of sustainable ways of living and the human dignity. It supports the rebirth of ecosystems to practise the sustainable use of natural resources, especially in the climate change era. Consequently, students are encouraged to present conflicts between different styles of consumption which are opposite to sustainable future. The long discussions expand students' understanding, build their set of values and teach them to value cross-generational responsibility.

\section{WELL-EDUCATED TEACHERS AS A PILLAR OF LEARNING IN SCHOOLS}

The beginnings of change in peruskoulu in Finland required from teachers, who previously taught in the academic grammar schools, the acquisitions of the abilities which enable them teach students with different skills. As Välijärvi advocated the comprehensive school reform was based on a new philosophy of education (Välijärvi et al., 2002), which involved the statements that all pupils can study in the appropriate opportunities and with teachers support. Finnish reforms were based on the new rules of conception of learning and conception of knowledge. In this perspective, the pupils "are active actors, who study to set goals and to solve problems both independently and together with others" (National Core Curriculum for Basic Education, 2014, p. 17). Sahlberg declares that (2015, p. 117) Finnish teachers are professionals who holistically teach and improve their working conditions. In the light of learning, Finnish teachers are perceived as Professional Community of learners, in which "in which the teachers in a school and its administrators continuously seek and share learning, and act on their learning. The goal of their actions is 'to enhance their effectiveness as professionals for the students' benefit" (Hord, 1997, p. 1).

From this perspective, it seems significant to add that Finnish basic schools value the collaboration among pupils, which contributes to creation of students' knowledge through social cooperation. In addition, schools also value teachers' collaboration in which "feelings of interdependence are central to such collaboration, [...] linking collaborative activity and achievement of shared purpose" (Hargreaves, 2003, p. 47). Teachers in Finland collaborate to design a "positive learning community for the students within the school environment" (National Core Curriculum for Basic Education, 2014, 
p. 38). Finnish teachers (Hargreaves \& Shirley, 2012, p. 65) explain and solve problems by a constant interaction rather than through public exposure of the problem.

The research-based teacher education has its roots in the wide knowledge about the most useful research in their subjects of teaching. Consequently, Finnish teachers are obliged to study the theoretical principles of a research studied at universities and after it and they are able to incorporate them in their lessons. Teachers' open-mindedness and their ability to draw the conclusions related to varied methodological sources are main parts of research-oriented approach in the contemporary teaching in Finland. Finnish teachers prepare their own curriculum with the acceptation of local education authorities. As a consequence, Finnish teachers contribute to needed supervision, regulations and promote success of Finnish students in the light of their learning orientation.

\section{CONCLUSIONS}

Values have heterogenous dimensions and they are envolved in the curriculum to design a school's mission. Seen in this perspective, values are like constructs; by affirming them, people decide what is good and what is bad, how they solve their problems and what they believe in. From this perspective, it seems significant that Finnish basic schools value the collaboration among pupils and teachers. Finnish basic school involves trust, which is perceived from the perspective of culture of trust and contributes to social trust among teachers. Trust is seen everywhere in Finnish basic schools. It is related to teachers autonomy in buiding their own curriculum, designing methods and preparing learning materials.

The analysis of the National Core Curriculum for Basic Education 2014 in Finland reveales the need to treat each child as unique and valuable. Values are embedded in the conception of learning in Finnish basic education and are parts of working approaches, school experiences and the learning process. They help students improve their learning skills and contribute, especially trust and equality to lifelong learning of students. They build students high-level of self-image, self- efficacy and self-esteem.

The document underlines the right of each child to a good education and to right to develop as part of democratic society. In this perspective, students who attend basic education, acquire set of values which enable them build 
their valuable life. Students know how to make decisions which influence on their whole life. Students are prepared to show respect to other people. Basic education values influence on learning, which promotes interactions between cultures in the light of sustainable development end eco-social knowledge. Values and learning consequently encourage long school discussions about cross-general responsibility for the Earth and human dignity. In addition, basic education values promote economic, social, regional and gender equality.

\section{REFERENCES}

BAIER, A. (1985). Trust and antitrust. Ethics, 96, 231-260.

Berkowitz, M. W. (1995). The education of the complete moral person. Aberdeen: Gordon Cook Foundation.

Berkowitz, M. W. (1996, November). The 'Plus One' convention revisited and beyond. Paper presented at the Annual Meeting of the Association for Moral Education, Ottawa, Canada.

Berkowitz, M. W. (1997, March). Integrating structure and content in moral education. Paper presented at the Annual Meeting of the American Educational Research Association, Chicago, IL.

Burnett, J. R. (1981). Whatever happened to John Dewey? In J. F. Soltis (Ed.), Philosophy of Education Since Mid Century (pp. 66-67). New York: Teachers College Press.

CHA£As, K. (2011). Moc wychowawcza przypadkowych zdarzeń w świetle introcepcji wartości. Kielce-Lublin: Wydawnictwo Jedność.

CHAŁAS, K., \& WiniARCZYK, E. (2018). Introcepcja wartości moralnych jako zadanie i wyzwanie dla nauczyciela edukacji wczesnoszkolnej. Lubelski Rocznik Pedagogiczny, 37(1), 143-153. DOI: $10.17951 / 1 r p .2018 .37 .1$

Chmaj, L. (1962). Prady i kierunki w pedagogice XX wieku. Warszawa: Państwowy Zakład Wydawnictw Szkolnych.

CORE Education. (2014). https://core-ed.org/research-and-innovation/ten-trends/2014/learnerorientation

Cunningham, W. G., \& Gresso, D. W. (1993). Cultural leadership. Boston: Allyn \& Bacon.

DeweY, J. (1958). Education and experience. New York: Collier Books.

Dewey, J. (1944/1991). Between two worlds. Later Works, 17, 451-465.

ENNI, R. H. (1994). Critical thinking dispositions: Theoretical and practical considerations in their delineation, endorsement, and assessment. Paper presented at the annual meeting of the American Educational Research Association, New Orleans.

Five U.S. innovations that helped Finland's schools improve but that American reformers now ignore. Retrieved January 10, 2021 from: https://www.washingtonpost.com/news/answersheet/wp/2014/07/25/five-u-s-innovations-that-helped-finlands-schools-improve-but-that-ame rican-reformers-now-ignore/

GearingUp Responsible and Outstanding Teachersin Southeast Asiafor the 21st Century or GURO21. Retrieved from: http://iflex.innotech.org/GURO21/module1/11_20.html 
GMEREK, T. (2005). Szkolnictwo wyższe w krajach skandynawskich, studium z pedagogiki porównawczej. Poznań: Wydawnictwo Wolumin.

GuteK, G. L. (1968). Pestalozzi and education. New York: Random House.

Hargreaves, A. (2003). Teaching in the knowledge society. Buckingham: Open University Press.

Hargreaves, A., \& Fullan, M. (2012). Professional capital. Transforming teaching in every school. New York: Teachers College Press.

Hargreaves, A., \& Shirley, D. (2012). The global fourth way, the quest for educational excellence. London: Sage Publications.

Homplewicz, J. (1996). Etyka pedagogiczna. Rzeszów: Wyższa Szkoła Pedagogiczna.

Hord, S. (1997). Professional learning communities: Communities of continuous inquiry and improvement. Austin, TX: Southwest Educational Development Laboratory. Retrieved from: https:// files.eric.ed.gov/fulltext/ED410659.pdf

Kupari, P., Reinikainen, P., Linnakylä, P., ArfFman, I., \& VäliJärVi, J. (2002). The Finnish success in PISA-and some reasons behind it. Jyväskylä, Finland: University of Jyväskylä, Institute for Educational Research, OECD.

Kupiainen, S., Hautamaki, J., \& Karjalainen, T. (2009). The Finnish education system, and PISA. Retrieved from: http://julkaisut.valtioneuvosto.fi/bitstream/handle/10024/75640/opm46.pdf? sequence $=1 \&$ is Allowed $=\mathrm{y}$

Learning to live together. UNESCO Office Bangkok and Regional Bureau for Education in Asia and the Pacific. Retrieved from: https://unesdoc.unesco.org/ark:/48223/pf0000227208

Łовоскі, M. (2000). Wartości tworzywem wychowania. In M. NowaK \& T. OżóG (Eds.), Wychowanie chrześcijańskie a kultura. Lublin: Wydawnictwo KUL.

ŁUKASIK, J. M., \& NowosAD, I. (2019). Przywództwo i zaufanie w środowisku szkolnym. Uwagi na kanwie rozwoju szkoły. Studia Edukacyjne, 52, 173-189.

MARIAŃSKI, J. (2000). Wartości jako przedmiot socjologiczny. In H. MieliCKA (Ed.), Socjologia wychowania. Wybór tekstów (pp. 225-230). Kielce: Wydawnictwo Stachurski.

National Core Curriculum for Basic Education 2014. (2016). Finnish National Agency for Education. Helsinki: Juvenes Print, Suomen Yliopistopaino Oy.

NowAK, M. (2019). Aksjologia współczesnej pedagogiki resocjalizacyjnej jako podstawa jej sukcesu. Roczniki Pedagogiczne, 11(47), 17-28.

Nowosad, I. (2018). Polityka edukacyjna Singapuru. Orientacja na jakość i efektywność. In R. NowakowsKa-SiUta \& K. DMiTruK-SierocińSKa (Eds.), Polityka oświatowa w perspektywie porównawczej (pp. 105-126). Kraków: Oficyna Wydawnicza "Impuls."

OECD. (2013). PISA 2012 results: Excellence through equity. Vol. 2. Paris. Retrieved from: https://www.oecd-ilibrary.org/education/pisa-2012-results-excellence-through-equity-volume-ii/to tal-variation-in-mathematics-performance-and-variation-between-and-within-schools_978926420 1132-graph11-en

OECD. (2018). PISA 2015, results in focus. Retrieved from: https://www.oecd.org/pisa/pisa2015-results-in-focus.pdf

OSER, F. K. (1994). Moral perspectives on teaching. Review of Research in Education, 20, 57-127.

PAUL, R. W. (1992). Critical thinking, what every person needs to survive in a rapidly changing world. Santa Rosa, CA: Foundation for Critical Thinking.

PINAR, W. F. (2004). What is curriculum theory? Mahwah, NJ - London: Lawrence Erlbaum Associates, Inc. 
Pollio, H. R., \& Beck, H. P. (2000). When the tail wags the dog: Perceptions of learning and grade orientation in, and by, contemporary college students and faculty. The Journal of Higher Education, 71, 84-102. DOI: 10.2307/2649283

SAHLberg, P. (2015). Finnish lessons. What can the world learn from educational change in Finland. New York: Columbia University.

Simola, H. (2005). The Finnish miracle of PISA: Historical and sociological remarks on teaching and teacher education. Comparative Education, 41(4), 455-470. DOI: 10.1080/03050060500317810

Suwalska, A. (2018). High-trust to teachers' job in Finland after 1970s. Studia z Teorii Wychowania, 9(3) (24), 273-287.

Suwalska, A. (2020). Relationship between the Finnish education and teachers' professional development in the perspective of contemporary challenges: Selected aspects. Kultura i Edukacja, 4(130), 9-24. DOI: 10.15804/kie.2020.04.01www.kultura-i-edukacja.pl

SzTOMPKA, P. (2007). Zaufanie. Fundament społeczeństwa. Kraków: Wydawnictwo Znak.

TIRRI, K. (2014). The last 40 years in Finnish teacher education. Journal of Education for Teaching, 40(5), 600-609. Retrieved from: http://dx.doi.org/10.1080/ 02607476.2014.9565455

Tyler, T., \& Kramer, R. M. (1996). “Whither trust?” In R. Kramer \& T. Tyler (Eds.), Trust in organizations (pp. 1-15). Thousand Oaks, CA: Sage.

Ustun, U., \& Eryilmaz, A. (2018). Analysis of Finnish Education System to question the reasons behind Finnish success in PISA. Studies in Educational Research and Development, 2(2), 93-114.

Välijärvi, J., Kupari, P., Linnakylä, P., Reinikainen, P., Sulkunen, S., Törnroos, J., \& ARFFMAN, I. (2007). The Finnish success in PISA - and some reasons behind it. Jyväskylä: Kirjapaino Oma Oy.

Veugelers, W. (2001). Teachers, values and critical thinking. In S. R. SteInberg (Ed.), Multi/ intercultural conversations (pp. 199-215). New York: Peter Lang.

Veugelers, W., \& Vedder, P. (2003). Values in teaching. Teachers and Teaching: Theory and Practice, 9(4), 377-390.

WODAK, R., \& KRZYZANOWSKI, M. (Eds.) (2008). Qualitative discourse analysis in the social sciences. New York: Palgrave Macmillan.

\section{VALUES AND THEIR INFLUENCE ON LEARNING \\ IN BASIC EDUCATION IN FINLAND—SELECTED ASPECTS}

\section{SUMMARY}

The article analyzes the context of the values that have been embedded in the learning process of both students and teachers in their professional development. The author presents the coherence of pillars based on solid theoretical foundations (J. Dewey), which made it possible to adapt the education system, and consequently schools, to learning based on values. In this scientific perspective, the article pays attention to values, which could be perceived as pillars of learning in basic education in Finland. In addition, the article concentrates on the phenomena of equality and trust, conception of learning and collaboration among teachers in Finnish basic education.

Keywords: values; values in Finnish basic education; learning and values; learning in the 21st century; trust; culture of trust; equality; conception of learning; collaboration among teachers. 


\section{WARTOŚCI I ICH WPŁYW NA UCZENIE SIE \\ W EDUKACJI PODSTAWOWEJ W FINLANDII - WYBRANE ASPEKTY}

\section{STRESZCZENIE}

Artykuł analizuje kontekst wartości, które zostały wpisane w proces uczenia się zarówno uczniów, jak i nauczycieli w ich rozwoju zawodowym. Autorka przedstawia spójność filarów opartą na solidnych podstawach teoretycznych (J. Dewey), co pozwoliło dostosować system edukacji, a co za tym idzie - także szkoły do uczenia się opartego na wartościach. W tej naukowej perspektywie artykuł zwraca uwagę na wartości, które w Finlandii mogą być postrzegane jako filary uczenia się w ramach edukacji podstawowej. Ponadto artykuł koncentruje się na zjawiskach równości i zaufania, koncepcji uczenia się i współpracy między nauczycielami w fińskiej edukacji podstawowej.

Słowa kluczowe: wartości; wartości w fińskiej edukacji podstawowej; uczenie się i wartości; uczenie się w XXI wieku; zaufanie; kultura zaufania; równość; koncepcja uczenia się; współpraca między nauczycielami. 